\title{
Transcatheter aortic valve implantation at a high-volume center: the Bad Rothenfelde experience
}

\author{
Marek Kowalski ${ }^{1}$, Cornelia Deutsch ${ }^{2}$, Steffen Hofmann ${ }^{1}$, Norbert Franz ${ }^{1,3}$, Michael Billion ${ }^{1}$, Abbas Ferdosi ${ }^{1}$, \\ Peter Bramlage ${ }^{2}$, Guram Imnadze ${ }^{4}$, Henning Warnecke $e^{1,3}$ \\ ${ }^{1}$ Schüchtermann Clinic, Bad Rothenfelde, Germany \\ ${ }^{2}$ Institute for Pharmacology and Preventive Medicine, Cloppenburg, Germany \\ ${ }^{3}$ Witten/Herdecke University, Witten, Germany \\ ${ }^{4}$ Department for Electrophysiology, Albertinen Heart and Vessel Center, Hamburg, Germany
}

Kardiochirurgia i Torakochirurgia Polska 2017; 14 (4): 215-224

\begin{abstract}
Introduction: The "transfemoral (TF) first" approach to access route selection in transcatheter aortic valve implantation (TAVI) is popular; however, the risk of major vascular complications is substantial. The "best for TF" approach identifies only the patients with ideal anatomy for TF-TAVI, potentially minimizing complications.

Aim: To characterize the outcomes of patients undergoing TAVI at a large-volume site that employs this approach.

Material and methods: Patients who underwent TAVI at the Bad Rothenfelde Heart Centre between 2008 and 2016 were consecutively enrolled. Findings were compared to those from large, multicenter registries.

Results: Of the 1,644 patients enrolled, 1,140 underwent TA- and 504 TF-TAVI. Comorbidities were more frequent in TA patients, who also had higher risk scores (EuroSCORE: 25.5\% vs. $21.2 \%$; STS score: $11.0 \%$ vs. $7.5 \%$; $p<0.001$ for both). Rates of conversion to open surgery, major vascular complications and intra-procedural mortality did not differ between groups. At 30 days, mortality rates were higher in the TA group (3.9\% vs. $1.9 \%, p=0.036)$. Stroke/transient ischemic attack and permanent pacemaker implantation rates did not differ significantly between groups ( $2.0 \%$ and $9.1 \%$ overall, respectively). Compared to multicenter registries, trends in mortality and complication rates were similar, though magnitudes were lower in the present study. In contrast with the present study, major vascular complication rates in multicenter registries are significantly higher for TF compared to TA patients.

Conclusions: At this high-volume center, the use of a "best for TF" approach to TAVI resulted in low mortality and complication rates.

Key words: transcatheter aortic valve implantation, transapical, transfemoral.
\end{abstract}

\section{Streszczenie}

Wstęp: Przezcewnikowe wszczepienie zastawki aortalnej (TAVI) w przypadku ciężkiej stenozy aortalnej jest powszechnie akceptowaną metodą leczenia odpowiednio wyselekcjonowanych pacjentów.

Cel: Celem badania jednoośrodkowego było retrospektywne porównanie wczesnych i odległych wyników terapii pacjentów leczonych z dostępu przezudowego i przezkoniuszkowego.

Materiat i metody: Do badania zakwalifikowano 1644 chorych (892 kobiety, 752 mężczyzn, średnia wieku: $81 \pm 5,8$ roku) poddanych przezcewnikowemu wszczepieniu zastawki aortalnej w Heart Center w Bad Rothenfelde w latach 2008-2016.

Wyniki: Z dostępu przezkoniuszkowego leczono 1140 pacjentów, a z dostępu przezudowego 504 (EuroSCORE: 25,5\% vs 21,2\%; STS score: $11,0 \%$ vs 7,5\%; $p<0,001)$. Konieczność konwersji do tradycyjnego zabiegu chirurgicznego, implantacji rozrusznika serca, duże komplikacje naczyniowe, powikłania zatorowe, jak również śmiertelność zabiegowa nie różniły się statystycznie w obu grupach. Śmiertelność 30-dniowa była wyższa u pacjentów leczonych przezkoniuszkowo w porównaniu z pacjentami leczonymi przezudowo (3,9\% vs $1,9 \%$, $p=0,036)$. W porównaniu z rejestrami wieloośrodkowymi śmiertelność i częstość komplikacji były podobne, natomiast częstość występowania dużych powikłań naczyniowych była mniejsza (szczególnie w przypadku dostępu przezudowego) w opisywanym badaniu.

Wnioski: Zgodna ze wskazaniami kwalifikacja pacjentów i właściwy wybór drogi dostępu do przezcewnikowego wszczepienia zastawki aortalnej prowadzi do optymalizacji wyników leczenia.

Słowa kluczowe: przezcewnikowe wszczepienie zastawki aortalnej, dostęp przezkoniuszkowy, dostęp przezudowy. 


\section{Introduction}

Transcatheter aortic valve implantation (TAVI) is growing in popularity for the treatment of severe aortic stenosis (AS). A number of access options exist, including transfemoral (TF), transapical (TA), transaortic (TAo), transaxillary/ subclavian and transcarotid. Of these, the retrograde TF and antegrade TA routes are most common.

The "TF-first" approach to the access route decision only considers patients for TA-TAVI once their anatomical eligibility for the TF route has been ruled out, resulting in prior studies reporting approximately two-thirds of patients undergoing TF-TAVI [1-3]. Use of TF access is becoming ever more popular amongst physicians, justified by TF-TAVI being less invasive [4], smaller diameter delivery devices becoming available, and the learning curve being shorter due to physician familiarity with percutaneous coronary intervention [5]. However, delivery devices travelling down lengthy vasculature have been associated with a higher risk of stroke and vascular damage [6]. Furthermore, retrograde crossing of the aortic arch may result in more difficult valve positioning. Therefore, care is needed when selecting patients for the TF route. The alternative "best for TF" approach favors the TA route for all patients unless they meet specific "ideal" TF access criteria, including appropriate diameter of target vasculature, minimal tortuosity, low-level calcification, and easily accessible valve position. This results in only $20 \%$ of patients undergoing TF-TAVI, with evidence suggesting lower rates of vascular complications and better clinical outcomes for both TA- and TF-TAVI patients [7].

Many of the studies comparing TA- to TF-TAVI include a mixture of sites, including those with low TAVI volumes. Clinical outcomes at a single, specialist, high-volume center may be expected to be superior to those reported by multicenter studies, given that surgical teams are more experienced and the learning curve is less significant. The Bad Rothenfelde Heart Centre is one such center, which employs the "best for TF" approach.

\begin{abstract}
Aim
We aimed to report the clinical outcomes of patients who underwent TA- or TF-TAVI at the Bad Rothenfelde Heart Centre between 2008 and 2016. We then compared our findings to those from large, multicenter registries, which included sites with low TAVI volumes and a "TF first" approach. This was with the aim of evaluating whether a single, high-volume, "best for TF" center could provide superior outcomes.
\end{abstract}

\section{Material and methods}

A single-center, prospective, observational registry of patients who underwent TAVI between 2008 and 2016 at the Bad Rothenfelde Heart Centre, Germany, was established as part of a quality assurance initiative. The present study is a retrospective analysis. The registry was approved by the responsible ethics committee in Hannover and performed in accordance with the declaration of Helsinki. All patients gave their written informed consent to participate.

\section{Patients}

Patients diagnosed with severe AS who were considered to be at prohibitively high risk for surgery, and were scheduled to undergo TF- or TA-TAVI, were consecutively enrolled. The decision to perform TAVI was made by the Bad Rothenfelde Heart Team (cardiologists, a cardiac surgeon and an imaging specialist) independently from the registry, as was the choice of access route. The latter was based on the "best for TF" approach, with only patients meeting all of the following six criteria scheduled to undergo TF-TAVI: target artery (common femoral/external iliac) diameter $\geq 1 \mathrm{~mm}$ larger than the outer diameter of the delivery sheath; minimal calcification at the entry site; no circular calcification between the entry site and abdominal aorta; no excessive calcification or atheroma in the aortic arch; no pronounced tortuosity of the aorta and iliac arteries; and no pronounced transverse position of the aortic valve. Any patient not meeting all of these criteria underwent TAVI via the TA route.

\section{Procedure, documentation and outcomes}

Prior to TAVI, baseline characteristics were documented and the most appropriate access route and valve size determined based on transesophageal echocardiography (TEE), coronary angiography, and a CT scan. All procedures were carried out under general anesthesia, according to the relevant standard protocols at the institution. Peri-procedural details were recorded, as were changes in post-TAVI echocardiographic parameters.

Follow-up visits and telephone interviews were carried out at 30 days, 6 months, 1 year, and every 12 months thereafter. The primary outcome was 30-day all-cause mortality, defined according to VARC-2 criteria [8]. Secondary outcomes included rates of peri-procedural complications (such as conversion to open surgery, major vascular complications, and acute kidney injury), and other 30-day outcomes defined by VARC-2 (including functional status, rates of stroke/TIA and PPI) [8]. Survival rates over 5 years were also assessed.

\section{Statistical analysis}

One-way ANOVA was used to test for differences in means between TA- and TF-TAVI patients. A $p$-value of $\leq 0.05$ was considered significant. Survival outcomes were illustrated using Kaplan-Meier curves.

\section{Results}

A total of 1,644 TAVI procedures were performed at the Bad Rothenfelde Heart Centre within the study period (Fig. 1). Of these, 1,140 (69.3\%) were performed via the TA, and 504 (30.7\%) via the TF access route.

\section{Baseline characteristics}

Patients had a mean age of $81.0 \pm 5.8$ years at baseline, which was not significantly different between TA and TF patients (Tab. I). A greater proportion of the TA group was 


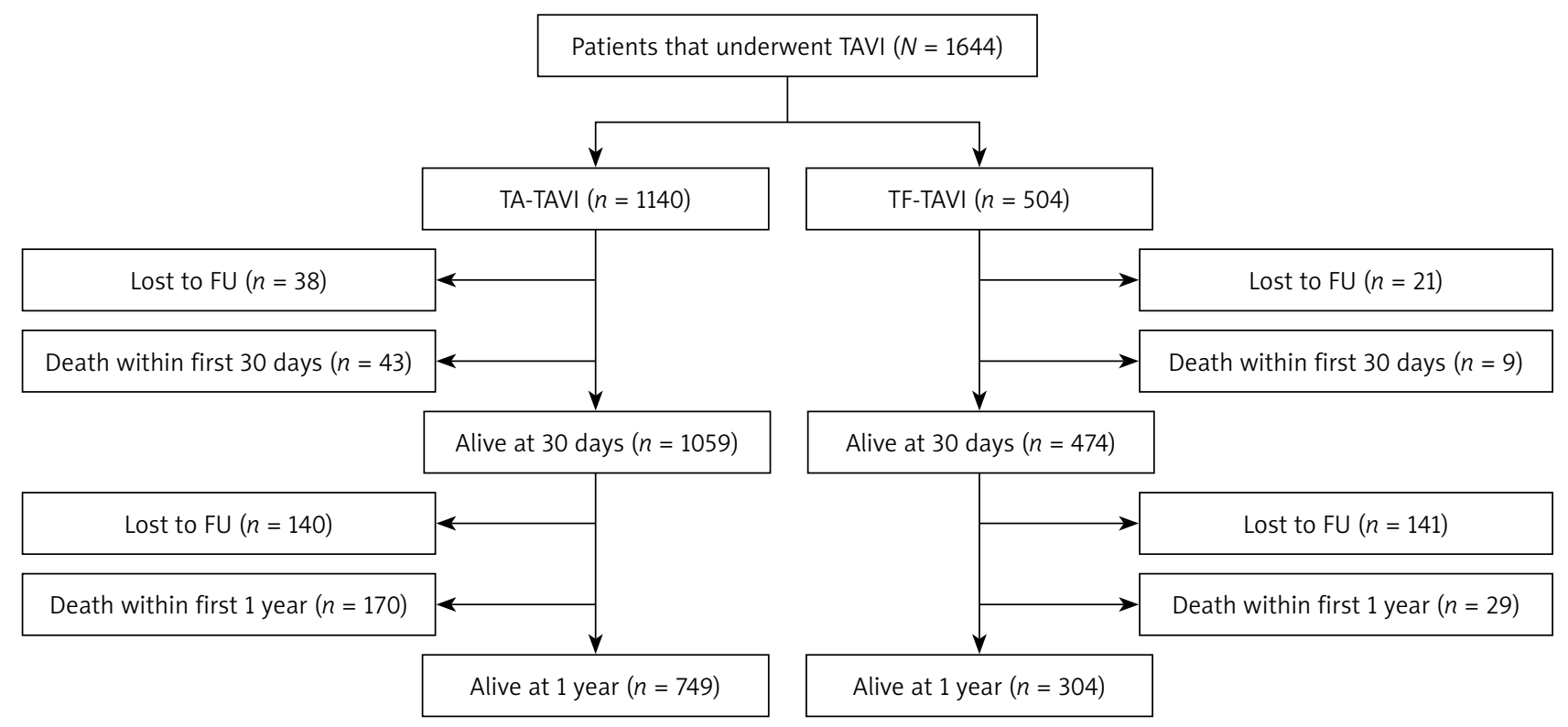

Fig. 1. Patient flow

FU - follow-up, TA - transapical, TF - transfemoral

Tab. I. Baseline characteristics

\begin{tabular}{|c|c|c|c|c|}
\hline \multirow[t]{2}{*}{ Parameter } & \multicolumn{3}{|c|}{ Mean $\pm \mathrm{SD} / n / N(\%)$} & \multirow[t]{2}{*}{$P$-value } \\
\hline & Total $(n=1644)$ & TA $(n=1140)$ & TF $(n=504)$ & \\
\hline Age [years] & $81.0 \pm 5.8$ & $80.9 \pm 6.0$ & $81.4 \pm 5.3$ & 0.110 \\
\hline Females & $892 / 1644(54.3)$ & $560 / 1140(49.1)$ & $332 / 504(65.9)$ & $<0.001$ \\
\hline \multicolumn{5}{|l|}{ Comorbidities: } \\
\hline Hypertension & $1551 / 1644(94.3)$ & $1089 / 1140(95.5)$ & $462 / 504(91.7)$ & 0.002 \\
\hline Coronary artery disease & $937 / 1620(57.8)$ & 724/1138 (63.6) & 213/482 (44.2) & $<0.001$ \\
\hline Previous myocardial infarction & 277/1621 (17.1) & 213/1141 (18.7) & 65/482 (13.5) & 0.012 \\
\hline Atrial fibrillation & $664 / 1644(40.4)$ & $493 / 1140(43.2)$ & 171/504 (33.9) & $<0.001$ \\
\hline Prior cardiac surgery ${ }^{a}$ & 408/1643 (24.8) & $347 / 1139(30.5)$ & $61 / 504(12.1)$ & $<0.001$ \\
\hline NYHA class III or IV & $1275 / 1569(81.3)$ & 926/1137 (81.4) & $349 / 432(80.8)$ & 0.766 \\
\hline Porcelain aorta & $463 / 1622(28.5)$ & $356 / 1139(31.3)$ & $107 / 483(22.2)$ & $<0.001$ \\
\hline Previous stroke & 257/1643 (15.6) & 201/1140 (17.6) & 56/503 (11.1) & 0.001 \\
\hline Pulmonary hypertension & $511 / 1642(31.1)$ & $329 / 1139(28.9)$ & $182 / 503(36.2)$ & 0.003 \\
\hline $\begin{array}{l}\text { Chronic obstructive pulmonary } \\
\text { disease }\end{array}$ & $332 / 1644(20.2)$ & $228 / 1140(20.0)$ & $104 / 504(20.6)$ & 0.767 \\
\hline Diabetes & $502 / 1644(30.5)$ & $363 / 1140(31.8)$ & $139 / 504(27.6)$ & 0.084 \\
\hline Renal insufficiency & 935/1642 (56.9) & 675/1139 (59.3) & $260 / 503(51.7)$ & 0.004 \\
\hline \multicolumn{5}{|l|}{ Aortic valve echocardiographic data: } \\
\hline Left ventricular ejection fraction & $53.5 \pm 12.8$ & $53.0 \pm 13.1$ & $54.6 \pm 12.3$ & 0.017 \\
\hline Peak gradient [mm Hg] & $76.4 \pm 25.1$ & $76.2 \pm 25.3$ & $76.9 \pm 24.6$ & 0.547 \\
\hline Mean gradient [mm Hg] & $47.4 \pm 16.6$ & $47.2 \pm 16.9$ & $47.7 \pm 16.0$ & 0.534 \\
\hline Log EuroSCORE I (\%): & $24.2 \pm 14.8$ & $25.5 \pm 15.3$ & $21.2 \pm 13.1$ & $<0.001$ \\
\hline Intermediate risk (<15\%) & $515 / 1635(31.5)$ & $325 / 1133(28.7)$ & $190 / 502(37.8)$ & $<0.001$ \\
\hline High risk $(\geq 15,<30 \%)$ & $673 / 1635(41.2)$ & 455/1133 (40.2) & $218 / 502(43.4)$ & \\
\hline Very high risk ( $\geq 30 \%)$ & 447/1635 (27.3) & $353 / 1133(31.2)$ & $94 / 502(18.7)$ & \\
\hline STS score (\%) & $9.9 \pm 9.4$ & $11.0 \pm 9.9$ & $7.3 \pm 7.5$ & $<0.001$ \\
\hline
\end{tabular}

EuroSCORE - European System for Cardiac Operative Risk Evaluation, NYHA - New York Heart Association, STS - Society of Thoracic Surgeons, TA - transapical, TF - transfemoral. aExcluding prior PCI. 
female. Transapical patients presented with greater comorbidity overall, though a larger proportion of TF patients had pulmonary hypertension.

Aortic valve (AV) peak and mean gradients (76.4 \pm 25.1 and $47.4 \pm 16.6 \mathrm{~mm} \mathrm{Hg}$, respectively) were comparable between groups. However, the mean left ventricular ejection fraction (LVEF) was slightly lower in TA patients (53.0 \pm 13.1 vs. $54.6 \pm 12.3, p=0.017$ ).

The mean logistic EuroSCORE was higher for the TA compared to the TF group ( $25.5 \pm 15.3 \%$ vs. $21.2 \pm 13.1 \%)$, as was the STS score $(11.0 \pm 9.9 \%$ vs. $7.3 \pm 7.5 \%, p<0.001)$.

\section{Procedural data}

Pre-dilation was performed in a significantly higher proportion of TF compared to TA patients (95.4\% vs. $53.4 \%$, $p<0.001$ ), with a longer procedural time in the former group $(71.2 \pm 26.5$ vs. $67.9 \pm 33.0 \mathrm{~min}, p=0.050)$ (Tab. II). The majority of patients received a SAPIEN/SAPIEN XT prosthesis (Edwards; 1,359 patients $(82.7 \%)$ ), with the remainder receiving an ACURATE valve (Symetis). No difference in the need for post-dilation was observed between groups. A second valve was required in six TA compared to no TF procedures ( $0.5 \%$ vs. $0 \%, p=0.186)$. The rates of all other procedural complications were low and comparable between groups.

\section{Post-procedural efficacy}

Compared to the TF group, the TA group had a lower post-TAVI V $V_{\max }(2.1 \pm 0.4$ vs. $2.3 \pm 0.4 \mathrm{~m} / \mathrm{s}, p<0.001)$, peak AV gradient (19.4 \pm 8.4 vs. $22.4 \pm 12.0 \mathrm{~mm} \mathrm{Hg}, p<0.001)$, and mean AV gradient (10.9 \pm 5.5 vs. $12.2 \pm 6.4 \mathrm{~mm} \mathrm{Hg}, p<$ 0.001) (Tab. II, Fig. 2). There was also a lower frequency of moderate/severe aortic insufficiency in the TA group $(0.5 \%$ vs. $1.7 \%, p=0.036)$, independent of valve type.

\section{0-day outcomes}

At 30 days after TAVI, a total of 59 patients (TA: 38 (3.3\%) patients; TF: 21 (4.2\%) patients) had been lost to follow-up. For the remaining patients, 30-day mortality rates were higher in the TA compared to TF group $3.9 \%$ vs. $1.9 \%, p=0.036$ ) (Tab. III), with a higher proportion

Tab. II. Peri-procedural details

\begin{tabular}{|c|c|c|c|c|}
\hline \multirow[t]{2}{*}{ Parameter } & \multicolumn{3}{|c|}{ Mean \pm SD or $n / N(\%)$} & \multirow[t]{2}{*}{ P-value } \\
\hline & Total $(n=1644)$ & $\mathrm{TA}(n=1140)$ & TF $(n=504)$ & \\
\hline Procedural time [min] & $68.9 \pm 31.2$ & $67.9 \pm 33.0$ & $71.2 \pm 26.5$ & 0.050 \\
\hline Valve type: & & & & $<0.001$ \\
\hline SAPIEN/SAPIEN XT & $1359 / 1644(82.7)$ & $913 / 1140(80.1)$ & $446 / 504(88.5)$ & \\
\hline ACURATE & 285/1644 (17.3) & 227/1140 (19.9) & $58 / 504(11.5)$ & \\
\hline Pre-dilation & $1090 / 1644(66.3)$ & $609 / 1140(53.4)$ & $481 / 504(95.4)$ & $<0.001$ \\
\hline Post-dilation & 282/1644 (17.2) & 195/1140 (17.1) & $87 / 504(17.3)$ & 0.931 \\
\hline \multicolumn{5}{|l|}{ Complications: } \\
\hline Procedural mortality & $5 / 1644(0.3)$ & $3 / 1142(0.3)$ & $2 / 504(0.4)$ & 0.645 \\
\hline Conversion to open surgery & $10 / 1644(0.6)$ & $7 / 1140(0.6)$ & $3 / 504(0.6)$ & 1.000 \\
\hline Second valve & $6 / 1644(0.4)$ & $6 / 1140(0.5)$ & $0 / 504(0)$ & 0.186 \\
\hline Vascular access complications: & & & & 0.163 \\
\hline Major vascular complications & $33 / 1622(2.0)$ & 21/1130 (1.9) & $12 / 492(2.4)$ & \\
\hline Minor vascular complications & $21 / 1622(1.3)$ & $11 / 1130(1.0)$ & $10 / 492(2.0)$ & \\
\hline Dialysis & $9 / 1621(0.6)$ & $9 / 1129(0.8)$ & $0 / 504(0)$ & 0.065 \\
\hline \multicolumn{5}{|l|}{ Aortic valve electrocardiographic parameters: } \\
\hline Peak velocity $[\mathrm{m} / \mathrm{s}]$ & $2.2 \pm 0.4$ & $2.1 \pm 0.4$ & $2.3 \pm 0.4$ & $<0.001$ \\
\hline Peak gradient [mm Hg] & $20.3 \pm 9.7$ & $19.4 \pm 8.4$ & $22.4 \pm 12.0$ & $<0.001$ \\
\hline Mean gradient [mm Hg] & $11.3 \pm 5.8$ & $10.9 \pm 5.5$ & $12.2 \pm 6.4$ & $<0.001$ \\
\hline Moderate/severe aortic insufficiency: & $14 / 1577(0.9)$ & $6 / 1109(0.5)$ & $8 / 468(1.7)$ & 0.036 \\
\hline SAPIEN/SAPIEN XT & $12 / 1301(0.9)$ & $5 / 886(0.6)$ & $7 / 415$ (1.7) & 0.062 \\
\hline ACURATE & $2 / 276(0.7)$ & $1 / 223(0.4)$ & $1 / 53(1.9)$ & 0.348 \\
\hline
\end{tabular}

TA - transapical, TF - transfemoral 
A

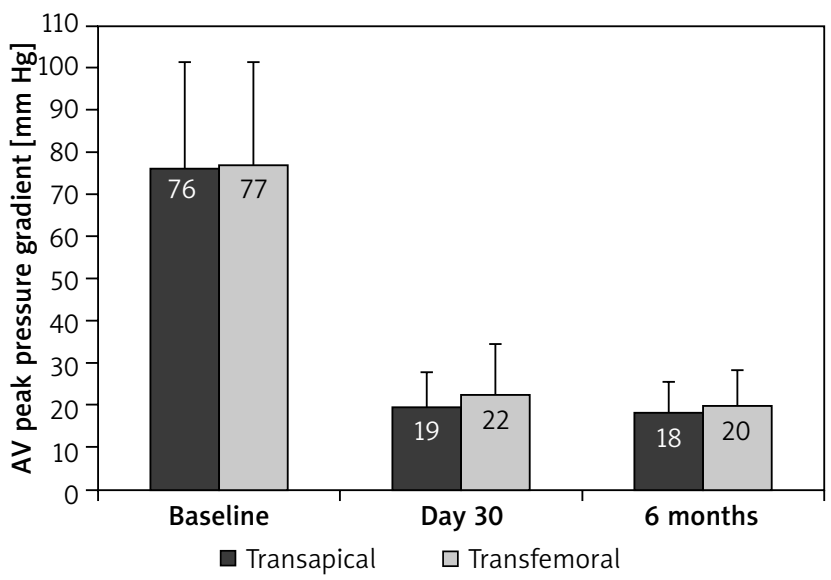

Fig. 2. Transvalvular pressure gradients at baseline and follow-up
B

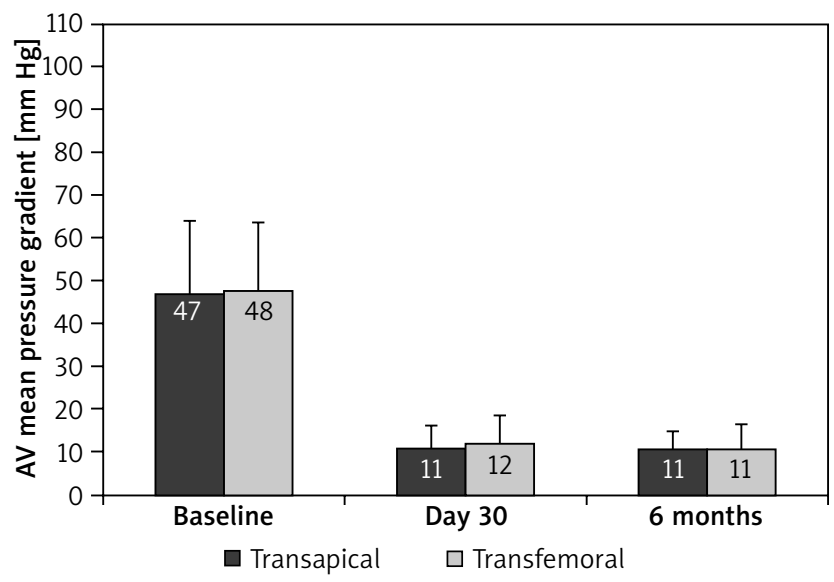

Tab. III. 30-day outcomes

\begin{tabular}{|c|c|c|c|c|}
\hline \multirow[t]{2}{*}{ Parameter } & \multicolumn{3}{|c|}{$n / N(\%)$} & \multirow[t]{2}{*}{$P$-value } \\
\hline & Total $(n=1585)$ & TA $(n=1102)$ & $\operatorname{TF}(n=483)$ & \\
\hline Mortality: & $52 / 1585(3.3)$ & 43/1102 (3.9) & 9/483 (1.9) & 0.036 \\
\hline Cardiovascular mortality & 25/1585 (1.6) & 21/1102 (1.9) & 4/483 (0.8) & 0.113 \\
\hline Non-cardiovascular mortality & 22/1585 (1.4) & 17/1102 (1.5) & $5 / 483(1.0)$ & 0.427 \\
\hline Unknown & $5 / 1585(0.3)$ & $5 / 1102(0.5)$ & $0 / 483(0)$ & 0.331 \\
\hline Stroke/transient ischemic attack & $32 / 1585(2.0)$ & 21/1102 (1.9) & $11 / 483(2.3)$ & 0.628 \\
\hline Permanent pacemaker: & $144 / 1585(9.1)$ & 92/1102 (8.3) & $52 / 483(10.8)$ & 0.123 \\
\hline SAPIEN/SAPIEN XT & $124 / 1307(9.5)$ & $76 / 878(8.7)$ & $48 / 429(11.2)$ & \\
\hline ACURATE & $20 / 278(7.2)$ & $16 / 224(7.1)$ & 4/54 (7.4) & \\
\hline
\end{tabular}

TA - transapical, TF - transfemoral

of cardiovascular death in the TA group (1.9\% vs. $0.8 \%$, $p=0.113)$. Stroke/TIA or PPI rates did not differ $(2.0 \%$ and $9.1 \%$ overall, respectively).

\section{Long-term functional status}

The proportion of patients in NYHA class III/IV fell considerably between baseline and 30-day follow-up, with a greater decrease in the TF compared to TA group $(-68.3 \%$ and $-50.0 \%$, respectively) (Fig. 3). From 6 months onwards, very little change was seen in NYHA class.

\section{Long-term survival}

Survival rates remained higher in the TF compared to TA group at all follow-up points up to 5 years (Fig. 4 A). This remained consistent when patients were stratified by the time period in which TAVI was carried out.

Increased survival rates were observed in patients who underwent the procedure more recently, irrespective of access route ( $p=0.007$ ) (Fig. 4 B). Survival at 2 years was $2.7 \%$ and $4.7 \%$ higher in patients who underwent TA and TF-TAVI, respectively, between 2012 and 2014 compared to those who underwent the procedure between 2008 and 2012.

\section{Discussion}

The Bad Rothenfelde Heart Centre has a high TAVI volume and takes a "best for TF" approach to access route selection. TA-TAVI was performed much more frequently than

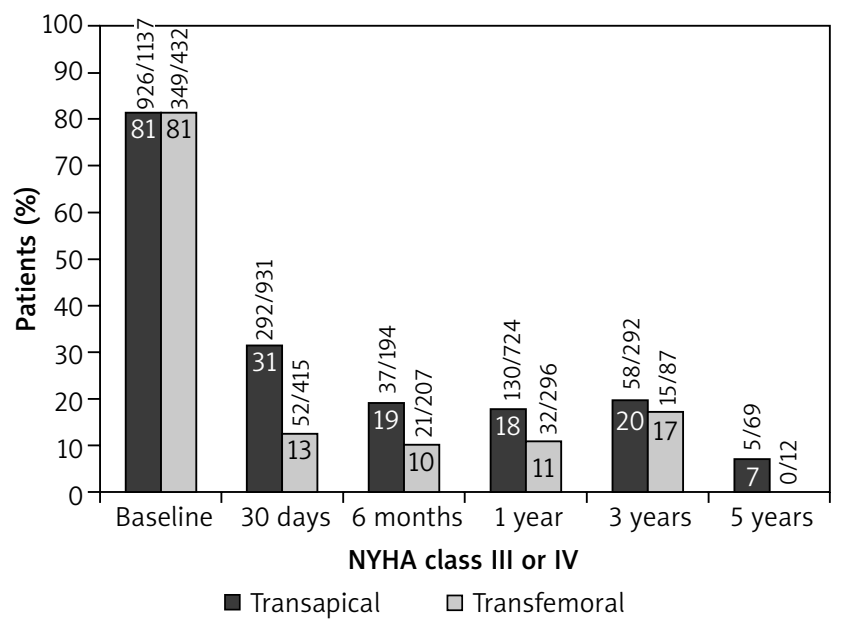

Fig. 3. Long-term changes in NYHA class NYHA - New York Heart Association 
A

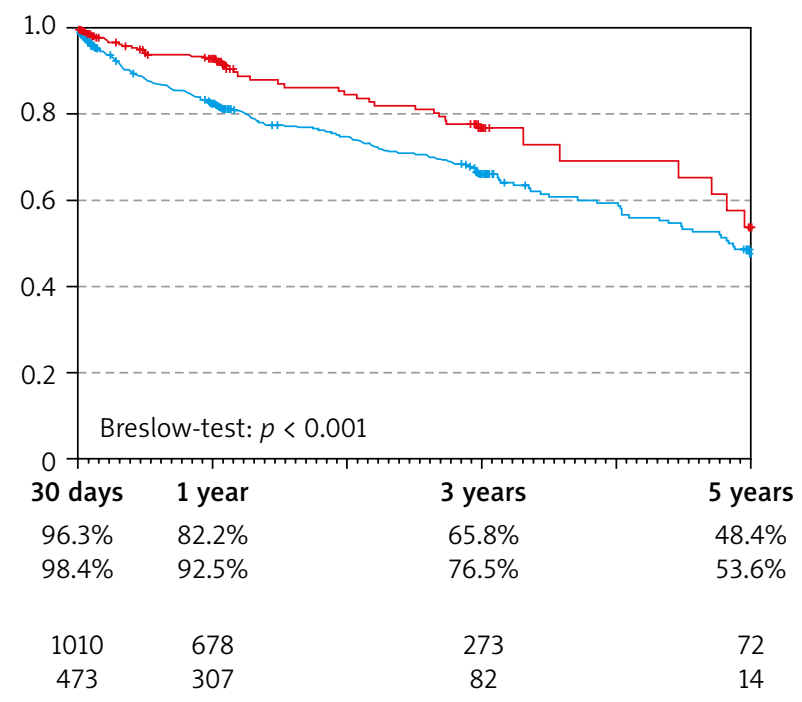

$\begin{array}{lcccc}\text { TA } & 96.3 \% & 82.2 \% & 65.8 \% & 48.4 \% \\ \text { TF } & 98.4 \% & 92.5 \% & 76.5 \% & 53.6 \% \\ \text { Patients at risk } & & & & \\ \text { TA }(n=1140) & 1010 & 678 & 273 & 72 \\ \text { TF }(n=473) & 473 & 307 & 82 & 14\end{array}$

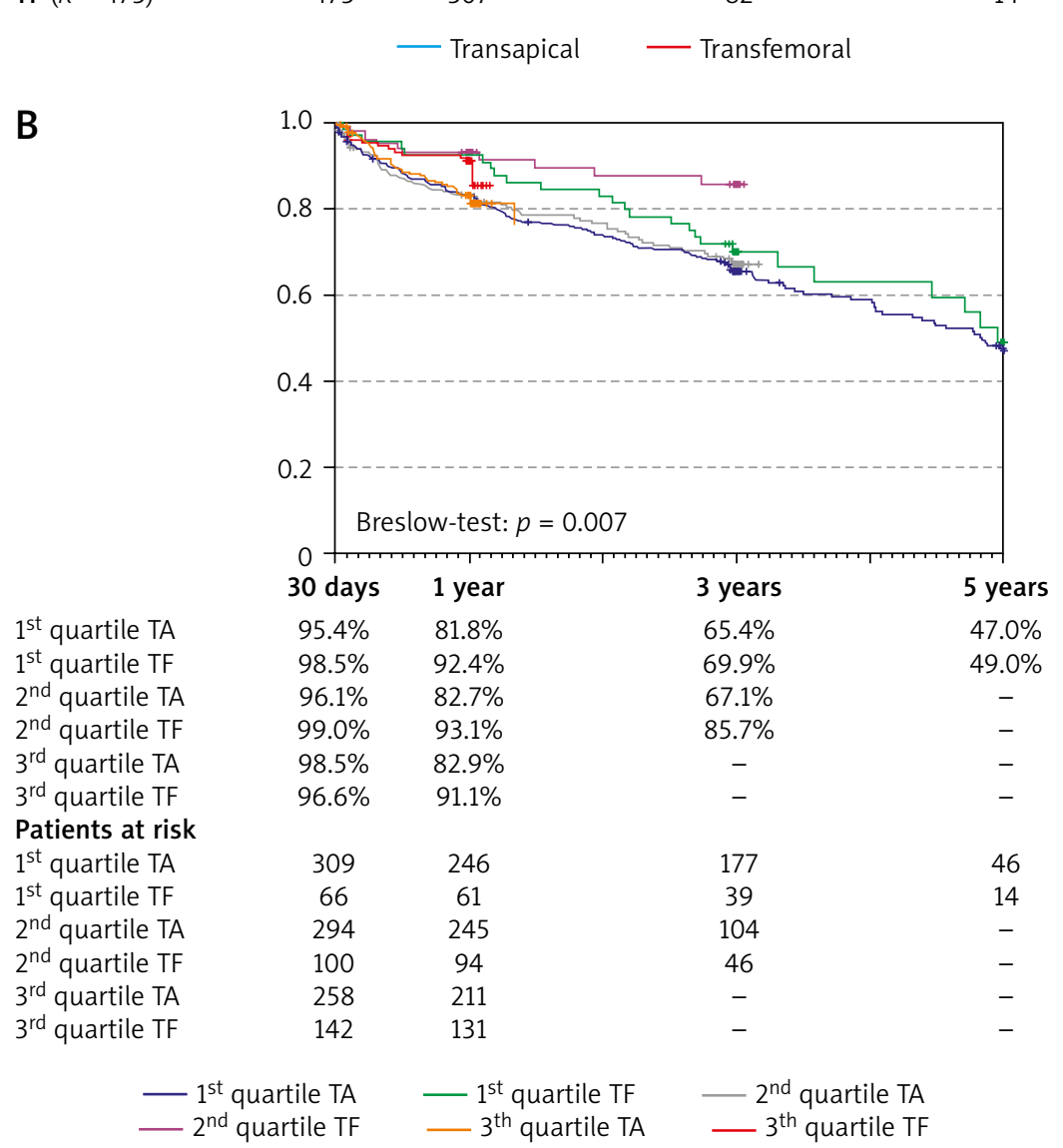

Fig. 4. Long-term survival. A - Kaplan-Meier survival for TA and TF groups. B - Kaplan-Meier survival curves for TA and TF groups, stratified by procedural time period. Curve flattening represents missing values. Patients who underwent TAVI $<1$ year before manuscript preparation ( $4^{\text {th }}$ quartile) were excluded

TA - transapical, TF - transfemoral

TF-TAVI at our site, with TA patients typically more comorbid and at a higher surgical risk. Accordingly, a higher rate of mortality was seen in the TA group, despite comparable rates of peri-procedural outcomes. While our trends regarding access route comparisons are generally in line with multicenter registries (Tab. IV), the magnitudes of mortality and complication rates appear to be consistently lower.
This suggests a possible clinical advantage of the "best for TF" approach at a high-volume, specialist site.

\section{Patient selection based on the "best for TF" approach}

Consistent with the literature, significantly higher comorbidity and surgical risk were observed in the TA group 
Tab. IV. Present outcomes compared to large multicenter registries

\begin{tabular}{|c|c|c|c|c|c|c|c|c|c|c|c|c|}
\hline Study & \multicolumn{2}{|c|}{ Current study } & \multicolumn{2}{|c|}{$\begin{array}{c}\text { Source } \\
{[16,20]}\end{array}$} & \multicolumn{2}{|c|}{$\begin{array}{c}\text { UK TAVI } \\
{[14]^{\mathrm{a}}}\end{array}$} & \multicolumn{2}{|c|}{$\begin{array}{c}\text { PRAGMATIC } \\
\text { [13] }\end{array}$} & \multicolumn{2}{|c|}{$\begin{array}{c}\text { SENTINEL } \\
{[15,27]}\end{array}$} & \multicolumn{2}{|c|}{$\begin{array}{c}\text { SWISS TAVI } \\
{[17]^{\mathrm{b}}}\end{array}$} \\
\hline Access decision approach & \multicolumn{2}{|c|}{ Best for TF } & \multicolumn{2}{|c|}{ HT decision } & \multicolumn{2}{|c|}{ TF-first } & \multicolumn{2}{|c|}{ TF-first } & \multicolumn{2}{|c|}{$\begin{array}{c}\text { NR } \\
\text { (TF-first } \\
\text { implied) }\end{array}$} & \multicolumn{2}{|c|}{$\begin{array}{c}\text { HT decision } \\
\text { (TF-first } \\
\text { implied) }\end{array}$} \\
\hline Centers & \multicolumn{2}{|c|}{1 German } & \multicolumn{2}{|c|}{34 European } & \multicolumn{2}{|c|}{30 UK } & \multicolumn{2}{|c|}{4 European } & \multicolumn{2}{|c|}{137 European } & \multicolumn{2}{|c|}{8 Swiss } \\
\hline Patients included & \multicolumn{2}{|c|}{1646} & \multicolumn{2}{|c|}{1038} & \multicolumn{2}{|c|}{795} & \multicolumn{2}{|c|}{882} & \multicolumn{2}{|c|}{4571} & \multicolumn{2}{|c|}{697} \\
\hline Timescale of implantation & \multicolumn{2}{|c|}{ 2008-2015 } & \multicolumn{2}{|c|}{ 2007-2009 } & 2007 & 2010 & $\begin{array}{r}\text { Start o } \\
2 C \\
\end{array}$ & $\begin{array}{l}\text { TAVI - } \\
1 \\
\end{array}$ & 2011 & 012 & 2011 & 2013 \\
\hline Parameter & TA & TF & TA & TF & TA & TF & TA & TF & TA & TF & TA & TF \\
\hline Procedures (\%) & 69.4 & 30.6 & 55.4 & 44.6 & 51.3 & 48.6 & 10.1 & 89.9 & 16.4 & 74.2 & 18.1 & 79.1 \\
\hline Baseline characteristics: & & & & & & & & & & & & \\
\hline Age [years] & 80.9 & 81.4 & 81.7 & 81.7 & 81.8 & 82.2 & 81.2 & 81.2 & NR & NR & 81.6 & 82.6 \\
\hline Female (\%) & 49.1 & 65.9 & 56.0 & 55.2 & 47.1 & 49.1 & 42.7 & 47.2 & 62.4 & 46.5 & 47.8 & 52.4 \\
\hline Hypertension (\%) & 95.5 & 91.7 & NR & NR & NR & NR & 79.8 & 67.6 & NR & NR & 86.2 & 81.4 \\
\hline CAD (\%) & 63.7 & 44.2 & 56.0 & 47.4 & 55.1 & 47.5 & 61.8 & 43.5 & 23.3 & 18.8 & 69.6 & 52.6 \\
\hline COPD (\%) & 20.1 & 20.2 & 29.4 & $25.4^{c}$ & $27.2^{c}$ & $26.6^{c}$ & 37.1 & 32.4 & 22.3 & 25.3 & 18.1 & 15.0 \\
\hline History of stroke (\%) & 17.7 & 11.1 & NR & NR & NR & NR & 20.2 & 15.3 & NR & NR & 12.3 & 11.8 \\
\hline History of MI (\%) & 18.7 & 13.5 & NR & NR & 19.9 & 20.9 & 15.7 & 16.3 & 22.1 & 15.4 & 15.9 & 14.8 \\
\hline Prior cardiac surgery (\%) & 30.6 & 12.1 & $26.9^{d}$ & $17.6^{d}$ & 40.0 & 20.9 & $39.3^{\mathrm{d}}$ & $21.1^{d}$ & 30.2 & 16.2 & 24.6 & 12.5 \\
\hline Renal insufficiency (\%) & 59.3 & 51.7 & 32.9 & 26.3 & NR & NR & NR & NR & NR & NR & $N R$ & NR \\
\hline Dialysis (\%) & 3.3 & 2.5 & NR & NR & NR & NR & NR & NR & 7.5 & 6.1 & NR & NR \\
\hline LVEF (\%) & 53.0 & 54.6 & NR & NR & NR & NR & NR & NR & NR & NR & 52.4 & 54.2 \\
\hline Log EuroSCORE (\%) & 25.6 & 21.2 & 29.1 & 25.7 & 22.5 & 17.7 & 27.0 & 20.0 & 22.2 & 19.6 & 22.5 & 19.6 \\
\hline Periprocedural data: & & & & & & & & & & & & \\
\hline Mortality (\%) & 0.3 & 0.4 & NR & NR & NR & NR & NR & NR & $12.8^{\mathrm{g}}$ & $5.9 \mathrm{~g}$ & NR & $N R$ \\
\hline Post-dilation (\%) & 17.1 & 17.3 & NR & NR & NR & NR & 10.1 & 12.6 & NR & NR & NR & NR \\
\hline Second valve (\%) & 1.0 & 0 & NR & NR & NR & NR & NR & NR & 2.2 & 2.6 & NR & NR \\
\hline Conversion to open surgery (\%) & 0.6 & 0.6 & 3.5 & 1.7 & NR & NR & NR & NR & 3.2 & 4.7 & NR & NR \\
\hline Major vascular complications (\%) & 1.8 & 2.4 & $2.4^{e}$ & $10.6^{\mathrm{e}}$ & $2.2^{f}$ & $9.0^{f}$ & 5.68 & $11.2^{g}$ & 2.2 & 2.9 & $0.0^{e, f}$ & $8.1^{e, f}$ \\
\hline 30-day outcomes: & & & & & & & & & & & & \\
\hline Mortality (\%) & 3.9 & 1.9 & 10.3 & 6.3 & 11.2 & 4.4 & 15.7 & 6.4 & NR & NR & 9.5 & 3.6 \\
\hline CV mortality (\%) & 1.9 & 0.8 & NR & NR & NR & NR & 12.4 & 5.7 & NR & NR & 9.5 & 3.6 \\
\hline Stroke/TIA (\%) & 1.9 & 2.3 & $2.6^{h}$ & $2.4^{h}$ & $3.4^{\mathrm{h}}$ & $3.3^{\text {h }}$ & 2.2 & 3.3 & NR & NR & 3.7 & 3.6 \\
\hline PPI (\%) & 8.3 & 10.8 & 7.3 & 6.7 & 7.4 & 6.7 & 15.7 & 15.7 & $N R$ & NR & 10.5 & 22.9 \\
\hline 1-year survival (\%) & $77.5^{i}$ & $88.2^{i}$ & 72.1 & 81.1 & 71.3 & 81.9 & 68.0 & 83.0 & NR & NR & $N R$ & NR \\
\hline 2-year survival (\%) & $68.6^{i}$ & $79.4^{i}$ & NR & NR & 44.0 & 56.5 & NR & NR & NR & NR & NR & NR \\
\hline
\end{tabular}

CAD - coronary artery disease, COPD - chronic obstructive pulmonary disease, CV - cardiovascular, HT - heart team, LVEF - left ventricular ejection fraction, $\mathrm{MI}$ - myocardial infarction, NR - not reported, PPI - permanent pacemaker implantation, TA - transapical, TF - transfemoral, TIA - transient ischemic attack. ${ }^{a}$ Data for SAPIEN valve only. ${ }^{b}$ Access groups are actually vascular (TF/subclavian) vs. surgical (TA/transaortic), but only $2.8 \%$ underwent TAVI via non-TA/TF routes. CPulmonary disease (not specifically COPD). ${ }^{\mathrm{d}}$ CABG only. ${ }^{\mathrm{e}} 30$-day rate. ${ }^{\mathrm{f}}$ Access site complications only. 8 |ncludes in-hospital rate. ${ }^{\mathrm{h}} \mathrm{Stroke}$ only (no TIA). ${ }^{2} 2008-2012$ quartile only. 
[1, 5, 9-17]. However, while other registries have typically reported history of $\mathrm{MI}$ and male gender to be evenly distributed between TA and TF groups [13, 14, 17], both were significantly more frequent in the TA group in our study. Given that males have a higher risk of $\mathrm{MI}$ than women $[18,19]$, it is unsurprising that the two go hand in hand. In an earlier study using the "best for TF" approach, a similar difference in gender distribution was seen (TA: $46 \%$ male; TF: $34 \%$ male; $p=0.01$ ) [7]. This may suggest that female peripheral vasculature is more compatible with TF access.

\section{Procedural data}

Approximately two-thirds of our patients underwent TA-TAVI, with only a third undergoing TF-TAVI. This is expected based on the "best for TF" approach, and reflects the smaller proportion of patients with "ideal" anatomy for TF-TAVI. Unsurprisingly, the majority of multicenter registries using the TF-first approach have reported the opposite trend $[13,15,17]$. Newer delivery devices have much smaller diameters than those used throughout the greater part of the data collection period. This will lead to increasingly higher proportions of patients satisfying the "best for TF" criteria, with a corresponding decrease in use of TA access.

In most large, multicenter registries, vascular complications occurred at a much higher rate in TF than TA patients, with the difference ranging from $5.6 \%$ to $8.2 \%$ [13, $14,16,17]$. Although a greater proportion of patients in our TF group experienced major vascular complications compared to the TA group, the difference was comparatively small $(0.6 \%)$. This appears to be driven by the low rate of major vascular complications in the TF group, which was nearly a quarter of that reported by the UK TAVI registry (9.0\%) [14]. A possible explanation is the greater compatibility between delivery devices and access vessel anatomy in TF-TAVI patients identified using the "best for TF" approach. However, differences in data collection periods and development of delivery devices over time should also be taken into account. Indeed, the more recent SENTINEL registry (2011-2012) reported very similar major vascular complication rates to the present study (TA: $2.2 \%$; TF: $2.9 \%$; $p=0.26$ ) [15], with the low rate in the TF group attributed to improvements in operator skill and the availability of smaller catheters.

In the present study, only $0.6 \%$ of patients in either group required conversion to open surgery. This is extremely low when compared to rates reported by the SOURCE and SENTINEL registries (TA: $3.5 \%$ and $3.2 \%$; TF: $1.7 \%$ and $4.7 \%$, respectively) $[15,16]$. Given that the SENTINEL study includes patients who underwent TAVI more recently, this is unlikely to be entirely due to time-dependent procedural and technological advancements. Furthermore, the SOURCE registry did not specifically employ a TF-first approach, relying instead on unbiased Heart Team assessment that resulted in $55.4 \%$ of procedures being performed via the TA route. This indicates that the approach to access selection is also unlikely to be responsible. We may therefore speculate that the high volume of TAVI patients at the Bad Rothenfelde
Heart Centre allowed for a higher degree of procedural familiarity and skill in the operative team, contributing to an extremely low rate of surgical conversion.

\section{0-day outcomes}

The 30-day mortality rate in the TA group was approximately double that of the TF group (3.9\% vs. $1.9 \%$, respectively). This ratio is consistent with findings from multicenter registries $[13,14,16,17]$, and is unsurprising, given the differences in baseline surgical risk. Indeed, when stratified by surgical risk scores, 30-day mortality rates were not significantly different between TA and TF patients. This lends support to the idea that early mortality in TAVI is principally associated with comorbidity.

The 30-day mortality rates in the present study were strikingly lower than those reported by the SOURCE, UK TAVI, PRAGMATIC and SWISS TAVI multicenter trials, which range from $9.5 \%$ to $15.7 \%$ for TA-TAVI and 3.6\% to $6.4 \%$ for TF-TAVI $[13,14,16,17]$. Furthermore, while multicenter registries that specify cause of death report almost all cases to be cardiovascular-related $[13,17]$, only half of our deaths at 30 days were of cardiovascular origin, regardless of access route. Considering that baseline values were similar across studies, patient factors are unlikely to be responsible for these differences. One explanation is the evolution of TAVI over time, which has resulted in improvements in valves and delivery devices and refinement of technique, alongside increasing operator experience [20-22]. These have been shown to translate into improvements in clinical parameters $[23,24]$. Consequently, we may expect patients enrolled during the latter portion of the study to have better outcomes than those enrolled early on, perhaps "diluting” 30-day mortality. However, a single-center TAVI registry spanning from 2008 to 2014 recently reported 30-day rates of $6.9 \%$ [25]. This is still relatively high, especially considering that the mean baseline EuroSCORE was only $14 \%$ (compared to $24.2 \%$ in the present study). Importantly, the study was carried out at a low-volume center, enrolling only 101 consecutive TAVI patients over nearly 4 years. This supports the argument for TAVI to be performed in experienced, high-volume centers, which may allow early recognition and intervention in situations known to result in mortality.

In our study, 30-day stroke/TIA rates were low and comparable between TA and TF groups (1.9\% and $2.3 \%$, respectively). Multicenter registries employing the TF-first approach have typically reported slightly higher rates, ranging from $2.2 \%$ to $3.7 \%$ for TA patients and 3.3 to $3.6 \%$ for TF patients $[13-15,17]$. This suggests that a high level of center expertise and the "best for TF" approach combined may reduce stroke/TIA rates in TAVI. This appears to be particularly true for TF-TAVI patients, likely due to the more rigorous selection process. However, rates of PPI were similar between groups in the present study, with medium values compared to those reported by multicenter registries [13-17]. Thus, PPI may not be influenced by center volume or access decision approach. 


\section{Long-term survival}

A higher rate of cumulative survival in the TF compared to the TA group was seen at all follow-up points up to 5 years. This trend has also been noted across multicenter clinical trials $[13,14,26]$, and likely reflects the generally greater degree of comorbidity in the TA patients. However, contemporary long-term survival data from multicenter TAVI registries are scarce, with the most recent findings reported for a population undergoing TAVI before 2012 [13]. Considering the global shift towards TAVI for lower-risk patients, advances in valve design, and procedural refinement, it is more appropriate to compare published survival rates to those of the earliest (2008-2012) quartile in the present study. While SOURCE, UK TAVI, and PRAGMATIC registries have reported 1-year survival rates ranging from $68.0 \%$ to $72.1 \%$ for TA-TAVI and $81.1 \%$ to $83.0 \%$ for TF-TAVI $[13,14,26]$, rates for our earliest quartile were somewhat higher $(77.5 \%$ and $88.2 \%$, respectively). Again, this may be due to more appropriate treatment and aftercare available from a highly experienced center.

\section{Limitations}

The main limitation of the present study was the lack of randomization, leading to an imbalance in baseline characteristics between groups. However, this reflects real-world clinical practice at our center at the time the registry data were collected, and allows the characterization of two distinct patient populations. Considering that TAVI has evolved rapidly over time, resulting in improved outcomes, comparing our data with those from older multicenter registries is problematic. Similarly, currently available delivery systems have smaller diameters than those used during the majority of the study. This will result in many more patients displaying the "ideal" characteristics for the TF approach, resulting in decreasing use of the TA approach. Performing TA-TAVI at high-volume centers then becomes even more important, as experience with the technique declines.

\section{Conclusions}

Despite the "best for TF" approach resulting in considerably lower proportions of TF and higher proportions of TA patients, the resulting group characteristics were not dissimilar to registries employing other approaches to access route selection. However, outcomes in both groups appeared nominally superior, particularly in terms of vascular complications and mortality. This is likely due to a combination of the expertise that accompanies a high-volume TAVI center, the "best for TF" approach to access route decision resulting in more appropriate patient selection, and improvements in TAVI over time. These data support the case for further evaluation of the "best for TF" approach, and suggest that clinical outcomes may be improved by the allocation of TAVI patients to specialist, experienced centers.

\section{Acknowledgments}

Editorial support was provided by Helen Sims (IPPMed, Terrassa, Spain).

\section{Disclosure}

One of the authors has disclosed potential conflicts of interest regarding the content herein. PB is a consultant for Edwards Lifesciences. No conflict of interest is declared by the other authors.

\section{References}

1. Blackstone EH, Suri RM, Rajeswaran J, Babaliaros V, Douglas PS, Fearon WF, Miller DC, Hahn RT, Kapadia S, Kirtane AJ, Kodali SK, Mack M, Szeto WY, Thourani VH, Tuzcu EM, Williams MR, Akin JJ, Leon MB, Svensson LG. Propensitymatched comparisons of clinical outcomes after transapical or transfemoral transcatheter aortic valve replacement: a placement of aortic transcatheter valves (PARTNER)-I trial substudy. Circulation 2015; 131: 1989-2000.

2. Avinee G, Durand E, Elhatimi S, Bauer F, Glinel B, Dacher JN, Cellier G, Viart G, Tron C, Godin M, Litzler PY, Cribier A, Eltchaninoff H. Trends over the past 4 years in population characteristics, 30-day outcomes and 1-year survival in patients treated with transcatheter aortic valve implantation. Arch Cardiovasc Dis 2016; 109: 457-464.

3. Toggweiler S, Leipsic J, Binder RK, Freeman M, Barbanti M, Heijmen RH, Wood DA, Webb JG. Management of vascular access in transcatheter aortic valve replacement: part 1: basic anatomy, imaging, sheaths, wires, and access routes. JACC Cardiovasc Interv 2013; 6: 643-653.

4. Walther T, Kempfert J, Mohr FW. Transcatheter aortic valve implantation: surgical perspectives. Arch Cardiovasc Dis 2012; 105: 174-180.

5. Schymik G, Wurth A, Bramlage P, Herbinger T, Heimeshoff M, Pilz L, Schymik JS, Wondraschek R, Suselbeck T, Gerhardus J, Luik A, Gonska BD, Posival $H$, Schmitt C, Schrofel $H$. Long-term results of transapical versus transfemoral TAVI in a real world population of 1000 patients with severe symptomatic aortic stenosis. Circ Cardiovasc Interv 2015; 8: pii: e000761. doi: 10.1161/CIRCINTERVENTIONS.113.000761.

6. Liu Z, He R, Wu C, Xia Y. Transfemoral versus transapical aortic implantation for aortic stenosis based on no significant difference in logistic EuroSCORE: a meta-analysis. Thorac Cardiovasc Surg 2016; 64: 374-381.

7. Imnadze G, Franz N, Hofmann S, Kowalski M, Billion M, Ferdosi A, Warnecke H. Benefits of "best for groin" strategy leading to a transapical TAVI dominance. Thorac Cardiovasc Surg 2015; 63: 487-492.

8. Kappetein AP, Head SJ, Genereux P, Piazza N, van Mieghem NM, Blackstone EH, Brott TG, Cohen DJ, Cutlip DE, van Es GA, Hahn RT, Kirtane AJ, Krucoff MW, Kodali S, Mack MJ, Mehran R, Rodes-Cabau J, Vranckx P, Webb JG, Windecker S, Serruys PW, Leon MB. Updated standardized endpoint definitions for transcatheter aortic valve implantation: the Valve Academic Research Consortium-2 consensus document (VARC-2). Eur J Cardiothorac Surg 2012; 42: S45-S60.

9. Rodes-Cabau J, Dumont E, Boone RH, Larose E, Bagur R, Gurvitch R, Bedard F, Doyle D, De Larochelliere R, Jayasuria C, Villeneuve J, Marrero A, Cote M, Pibarot P, Webb JG. Cerebral embolism following transcatheter aortic valve implantation: comparison of transfemoral and transapical approaches. J Am Coll Cardiol 2011; 57: 18-28.

10. Ewe SH, Delgado V, Ng AC, Antoni ML, van der Kley F, Marsan NA, de Weger A, Tavilla G, Holman ER, Schalij MJ, Bax JJ. Outcomes after transcatheter aortic valve implantation: transfemoral versus transapical approach. Ann Thorac Surg 2011; 92: 1244-1251.

11. Bleiziffer S, Ruge H, Mazzitelli D, Hutter A, Opitz A, Bauernschmitt R, Lange R. Survival after transapical and transfemoral aortic valve implantation: talking about two different patient populations. J Thorac Cardiovasc Surg 2009; 138: 1073-1080.

12. Szeto WY, Augoustides JG, Desai ND, Moeller P, McGarvey ML, Walsh E, Bannan A, Herrmann HC, Bavaria JE. Cerebral embolic exposure during transfemoral and transapical transcatheter aortic valve replacement. J Card Surg 2011; 26: 348-354.

13. van der Boon RM, Marcheix B, Tchetche D, Chieffo A, Van Mieghem NM, Dumonteil N, Vahdat O, Maisano F, Serruys PW, Kappetein AP, Fajadet J, Colombo A, Carrie D, van Domburg RT, de Jaegere PP. Transapical versus transfemoral aortic valve implantation: a multicenter collaborative study. Ann Thorac Surg 2014; 97: 22-28.

14. Blackman DJ, Baxter PD, Gale CP, Moat NE, Maccarthy PA, Hildick-Smith D, Trivedi U, Cunningham D, De Belder MA, Ludman PF; National Institute for Cardiovascular Outcomes, Research. Do outcomes from transcatheter aortic 
valve implantation vary according to access route and valve type? The UK TAVI Registry. J Interv Cardiol 2014; 27: 86-95.

15. Di Mario C, Eltchaninoff H, Moat N, Goicolea J, Ussia GP, Kala P, Wenaweser P, Zembala M, Nickenig G, Alegria Barrero E, Snow T, lung B, Zamorano P, Schuler G, Corti R, Alfieri O, Prendergast B, Ludman P, Windecker S, Sabate M, Gilard M, Witowski A, Danenberg H, Schroeder E, Romeo F, Macaya C, Derumeaux G, Maggioni A, Tavazzi L; Transcatheter Valve Treatment Sentinel Registry Investigators of the, EURObservational Research Programme of the European Society of Cardiology. The 2011-12 pilot European Sentinel Registry of Transcatheter Aortic Valve Implantation: in-hospital results in 4,571 patients. Eurolntervention 2013; 8: 1362-1371.

16. Thomas M, Schymik G, Walther T, Himbert D, Lefevre T, Treede H, Eggebrecht H, Rubino P, Michev I, Lange R, Anderson WN, Wendler O. Thirty-day results of the SAPIEN aortic Bioprosthesis European Outcome (SOURCE) Registry: a European registry of transcatheter aortic valve implantation using the Edwards SAPIEN valve. Circulation 2010; 122: 62-69.

17. Wenaweser P, Stortecky S, Heg D, Tueller D, Nietlispach F, Falk V, Pedrazzini G, Jeger R, Reuthebuch O, Carrel T, Raber L, Amann FW, Ferrari E, Toggweiler S, Noble S, Roffi M, Gruenenfelder J, Juni P, Windecker S, Huber C. Short-term clinical outcomes among patients undergoing transcatheter aortic valve implantation in Switzerland: the Swiss TAVI registry. Eurolntervention 2014; 10: 982-989.

18. Lundblad D, Holmgren L, Jansson JH, Näslund U, Eliasson M. Gender differences in trends of acute myocardial infarction events: The Northern Sweden MONICA study 1985-2004. BMC Cardiovasc Dis 2008; 8: 17.

19. Kyto V, Sipila J, Rautava P. Association of age and gender with risk for nonST-elevation myocardial infarction. Eur J Prev Cardiol 2015; 22: 1003-1008.
20. Hayashida K, Lefevre T, Chevalier B, Hovasse T, Romano M, Garot P, Mylotte D, Uribe J, Farge A, Donzeau-Gouge P, Bouvier E, Cormier B, Morice MC. Transfemoral aortic valve implantation new criteria to predict vascular complications. JACC Cardiovasc Interv 2011; 4: 851-858.

21. Fanning JP, Platts DG, Walters DL, Fraser JF. Transcatheter aortic valve implantation (TAVI): valve design and evolution. Int J Cardiol 2013; 168: 18221831.

22. Bourantas CV, Serruys PW. Evolution of transcatheter aortic valve replacement. Circ Res 2014; 114: 1037-1051.

23. Puri R, Rodes-Cabau J. Transcatheter aortic valve replacement: a revolution in evolution. JACC Cardiovasc Interv 2016; 9: 364-366.

24. Arai T, Lefevre T, Hovasse T, Morice MC, Garot P, Benamer H, Unterseeh T, Hayashida K, Watanabe Y, Bouvier E, Cormier B, Chevalier B. Comparison of Edwards SAPIEN 3 versus SAPIEN XT in transfemoral transcatheter aortic valve implantation: difference of valve selection in the real world. J Cardiol 2017; 69: 565-569.

25. Bagienski M, Kleczynski P, Dziewierz A, Rzeszutko L, Sorysz D, Trebacz J, Sobczynski R, Tomala M, Stapor M, Gackowski A, Dudek D. Early- and mid-term outcomes after transcatheter aortic valve implantation. Data from a singlecenter registry. Adv Interv Cardiol 2016; 12: 122-127.

26. Thomas M, Schymik G, Walther T, Himbert D, Lefevre T, Treede H, Eggebrecht H, Rubino P, Colombo A, Lange R, Schwarz RR, Wendler O. One-year outcomes of cohort 1 in the Edwards SAPIEN Aortic Bioprosthesis European Outcome (SOURCE) registry: the European registry of transcatheter aortic valve implantation using the Edwards SAPIEN valve. Circulation 2011; 124: 425-433. 